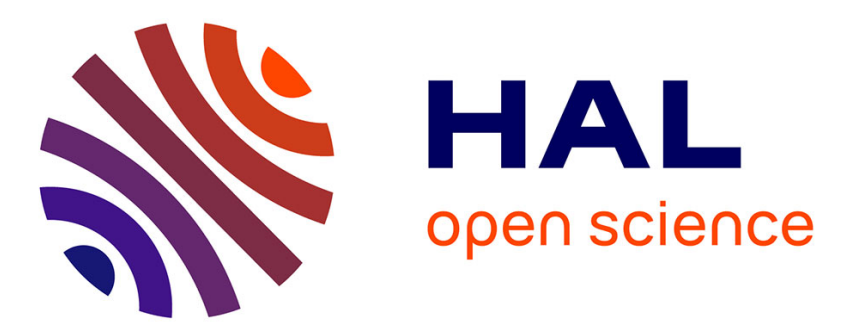

\title{
Moroccan plants as potential chemosensitisers restoring antibiotic activity in resistant Gram-negative bacteria
}

Mariam Fadli, Jacqueline Chevalier, Asmaa Saad, Nour-Eddine Mezrioui, Lahcen Hassani, Jean-Marie Pages

\section{- To cite this version:}

Mariam Fadli, Jacqueline Chevalier, Asmaa Saad, Nour-Eddine Mezrioui, Lahcen Hassani, et al.. Moroccan plants as potential chemosensitisers restoring antibiotic activity in resistant Gram-negative bacteria. International Journal of Antimicrobial Agents, 2011, 38 (4), pp.325. 10.1016/j.ijantimicag.2011.05.005 . hal-00725397

\section{HAL Id: hal-00725397 https://hal.science/hal-00725397}

Submitted on 26 Aug 2012

HAL is a multi-disciplinary open access archive for the deposit and dissemination of scientific research documents, whether they are published or not. The documents may come from teaching and research institutions in France or abroad, or from public or private research centers.
L'archive ouverte pluridisciplinaire HAL, est destinée au dépôt et à la diffusion de documents scientifiques de niveau recherche, publiés ou non, émanant des établissements d'enseignement et de recherche français ou étrangers, des laboratoires publics ou privés. 


\section{Accepted Manuscript}

Title: Moroccan plants as potential chemosensitisers restoring antibiotic activity in resistant Gram-negative bacteria

Authors: Mariam Fadli, Jacqueline Chevalier, Asmaa Saad, Nour-Eddine Mezrioui, Lahcen Hassani, Jean-Marie Pages

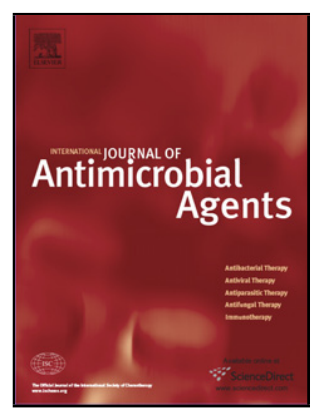

PII:

S0924-8579(11)00236-6

DOI: doi:10.1016/j.ijantimicag.2011.05.005

Reference: ANTAGE 3630

To appear in: International Journal of Antimicrobial Agents

Received date: $\quad 28-2-2011$

Revised date: $\quad 29-4-2011$

Accepted date: $\quad 3-5-2011$

Please cite this article as: Fadli M, Chevalier J, Saad A, Mezrioui N-E, Hassani L, Pages J-M, Moroccan plants as potential chemosensitisers restoring antibiotic activity in resistant Gram-negative bacteria, International Journal of Antimicrobial Agents (2010), doi:10.1016/j.ijantimicag.2011.05.005

This is a PDF file of an unedited manuscript that has been accepted for publication. As a service to our customers we are providing this early version of the manuscript. The manuscript will undergo copyediting, typesetting, and review of the resulting proof before it is published in its final form. Please note that during the production process errors may be discovered which could affect the content, and all legal disclaimers that apply to the journal pertain. 


\section{Essential oils from Moroccan plants as potential chemosensitisers restoring antibiotic activity in resistant Gram-negative bacteria}

Mariam Fadli ${ }^{a, b}$, Jacqueline Chevalier ${ }^{a}$, Asmaa Saad ${ }^{b}$, Nour-Eddine Mezrioui ${ }^{b}$, Lahcen Hassani $^{\mathrm{b}}$, Jean-Marie Pages ${ }^{\mathrm{a}, *}$

a UMR-MD1, Facultés de Médecine et de Pharmacie, Université de la Méditerranée, IFR88, Marseille, France

${ }^{\mathrm{b}}$ Laboratory of Biology and Biotechnology of Microorganisms, Faculty of Science, Université Cadi Ayyad, Marrakech, Morocco

ARTICLE INFO

Article history:

Received 28 February 2011

Accepted 3 May 2011

Keywords:

Antibiotics

Antibiotic resistance

Chemosensitisers

Efflux pumps inhibitors

Efflux systems

Essential oils

Gram-negative bacteria

Multidrug resistance 
* Corresponding author. UMR-MD1, Transporteurs Membranaires, Chimiorésistance et Drug Design, Faculté de Médecine, 27 Bd Jean Moulin, 13385 Marseille cedex 05, France. Tel.: +334913245 87; fax: +33491324606.

E-mail address: jean-marie.pages@univmed.fr (J.-M. Pages). 


\section{ABSTRACT}

Bacterial drug resistance is a worrying public health problem. Antibiotic efflux is a major non-specific resistance mechanism used by bacteria, and efflux pumps are involved in the low-level susceptibility of various important Gram-negative pathogens. Use of molecules that can block bacterial pumps is an attractive strategy, but several studies report only partial efficacy owing to limits of these molecules (stability, selectivity, bioavailability, toxicity, etc.). The objective of this study was to search for natural sources of molecules able to inhibit efflux pump systems of resistant Gram-negative bacteria (Escherichia coli, Enterobacter aerogenes, Klebsiella pneumoniae, Salmonella enterica serotype Typhimurium and Pseudomonas aeruginosa). The results indicate that the studied essential oils exhibit interesting activity against the tested bacteria. This activity was significantly enhanced in the presence of an efflux pump inhibitor such as phenylalanine arginyl $\beta$-naphthylamide (PA $\beta N)$. The role of lipopolysaccharide (LPS) structure in the effect of essential oils was also reported in Salmonella LPS deep-rough mutants. In addition, essential oils of Thymus maroccanus and Thymus broussonetii, used at a low concentration (a fraction of the minimum inhibitory concentration), are able to significantly increase chloramphenicol susceptibility of several resistant isolates. These results demonstrate that these essential oils can alter efflux pump activity and may be attractive candidates to develop new drugs for chemosensitising multidrugresistant strains to clinically used antibiotics. 


\section{Introduction}

The continued emergence and spread of multidrug-resistant (MDR) bacteria strongly impairs the efficacy of antibiotics and is of growing concern for human health [1,2]. Three main mechanisms are involved in bacterial resistance to antibiotics: production of enzymes that inactivate the antibiotics [3]; modification or masking of the antibiotic target, inhibiting their antibacterial action [4,5]; and modification of the membrane organisation, which includes alteration of membrane permeability and the expression of transporters expelling the antibiotic outside the cell [6-8]. This drug transport is associated with the expression of efflux pumps [7]. These membrane transporters, classified into five families, can confer resistance to a specific class of antibiotics or to a large number of drugs [8,9]. The latter group of efflux pumps, such as the AcrAB family, can handle a wide variety of structurally unrelated compounds [8-11] and the majority of antibiotic families are recognised and expelled by efflux pumps, including quinolones, $\beta$-lactams, phenicols, tetracyclines and aminoglycosides [11,12].

With increasing evidence demonstrating the involvement of efflux pumps in the antibiotic resistance detected in clinical isolates, many studies are engaged in developing molecules capable of blocking, at least partially, the action of the efflux pumps and that therefore have the potential to circumvent antimicrobial resistance $[9,11,13]$. Several molecules have been characterised for their inhibitory ability, such as phenylalanine arginyl $\beta$-naphthylamide $(\mathrm{PA} \beta \mathrm{N})$, carbonyl cyanide $m$ chlorophenylhydrazone and reserpine [13-18]. Use of bacterial pump inhibitors is attractive because it is an original anti-resistance approach that can be active on 
several efflux-producing bacteria, and these compounds may restore activity for different families of antibiotics $[13,19]$. However, their clinical use is difficult owing to the toxicity, stability, selectivity and bioavailability of available molecules $[17,19]$.

Natural products such as plant oils provide a wide diversity of chemical structures that exhibit broad-spectrum activity. Over the past few years, several natural compounds acting as efflux pumps inhibitors have been investigated [10,20-23]. Some of them are able to restore the activity of usual antibiotics on resistant clinical bacteria isolated during therapeutic treatment.

The aim of this present study was (i) to evaluate the activity of some Moroccan essential oils on different MDR isolates expressing efflux mechanisms and (ii) to test their capability, when used in combination, to restore antibiotic efficacy by blocking the drug efflux pumps expressed in the isolates.

\section{Material and methods}

\subsection{Bacterial strains}

The Gram-negative bacteria used in this study are listed in Table 1. Enterobacter aerogenes ATCC 13048 [18], Escherichia coli AG100, Pseudomonas aeruginosa PA01 and Salmonella enterica serotype Typhimurium SL696 were used as control strains. Enterobacter aerogenes EAEP289 is a kanamycin-sensitive derivative of EA27 (MDR isolate that exhibits active efflux of norfloxacin and chloramphenicol). EAEP294 is an acrA mutant constructed from EAEP289 [24]. Escherichia coli AG100A is kanamycin-resistant deleted of AcrAB and hypersusceptible to 
chloramphenicol, tetracycline, ampicillin and nalidixic acid [25]. AG102 overproducing AcrAB is an AG100 derivative [26]. Klebsiella pneumoniae KPBj1E+ is a clinical isolate showing resistance to cefoxitin, quinolones and chloramphenicol associated with the expression of an efflux system. KPBj1Rev is a reverted strain derivative of $\mathrm{KPBj} 1 \mathrm{E}+$ that spontaneously becomes susceptible to the three antibiotic families [27]. Salmonella Typhimurium SL1069 and SL1102 are derivative strains from SL696 with deletion of a small and a large part of lipopolysaccharide (LPS), respectively [28]. Pseudomonas aeruginosa PA124 is a clinical isolate that overproduces OprM [21].

Strains were preserved at $4{ }^{\circ} \mathrm{C}$ and were grown on Luria-Bertani agar $24 \mathrm{~h}$ prior to any assay. Mueller-Hinton broth (MHB) was used for the antibiotic susceptibility tests.

\subsection{Plant material and essential oils}

Aerial parts of Thymus broussonetii, Thymus maroccanus, Thymus pallidus and Rosmarinus officinalis, belonging to the Lamiaceae family, were collected at full flowering stage in 2009 from different regions of Morocco. Identification of plant material was confirmed by Prof. Ahmed Ouhammou, a plant taxonomist in the Laboratory of Ecology and Environment of the University Cadi Ayyad (Marrakech, Morocco), where the voucher specimens were deposited. Dry aerial material of plants was subjected to hydrodistillation for $4 \mathrm{~h}$. The oil recovered was stored in darkness at $4{ }^{\circ} \mathrm{C}$ until use in bioassays. 
The method for gas chromatography/mass spectroscopy (GC/MS) has been described previously [29]. Briefly, analysis of the essential oils was carried out using GC/MS (Agilent Technologies, Palo Alto, CA) and the appropriate conditions (carrier gas, injector, times and temperatures). Identification of components was assigned by matching their mass spectra with Wiley and NIST library data, standards of the main components and by comparing their Kovats retention indices with reference libraries as described [29]. The component concentration was obtained by semiquantification by peak area integration from GC peaks and by applying the correction factors $[29,30]$.

\subsection{Minimum inhibitory concentration (MIC) determination}

MIC assays were performed by microdilution assay. Each compound was analysed using a two-fold dilution series prepared in dimethyl sulphoxide (DMSO) (4\%). Microwells containing $100 \mu \mathrm{L}$ of oil dilution were inoculated with $100 \mu \mathrm{L}$ of cell suspension prepared by diluting an overnight culture in MHB twice concentrated to obtain viable counts of ca. $10^{6}$ colony-forming units $/ \mathrm{mL}$ at a final DMSO concentration of $2 \%$. At this concentration, no significant effect has been observed on the bacteria tested as control under these conditions. The inoculated microplates were incubated at $37^{\circ} \mathrm{C}$ for $18-24 \mathrm{~h}$. The MIC was defined as the lowest concentration of essential oil inhibiting visible growth of the test strain. Chloramphenicol, cloxacillin and norfloxacin were used as usual antibiotics.

The MIC of essential oils was determined in combination with PA $\beta N$ at a final concentration of $20 \mathrm{mg} / \mathrm{L}$, whereas synergy between antibiotics and essential oils was studied using essential oils at a low concentration (fraction of the MIC). Assays 
were repeated three times on separate days and similar results were obtained in each experiment.

\section{Results}

Previous GC/MS analysis had indicated that carvacrol $(76.35 \%)$ was the major constituent in $T$. maroccanus essential oil in addition to other constituents exhibiting relatively low concentrations. Thymus broussonetii was found to be richer qualitatively and it is mainly composed of carvacrol $(39.77 \%)$, borneol $(12.03 \%)$, bicyclogermacrene (7.95\%), thymol (4.98\%) and terpinene (4.09\%) [30]. The chemical composition of $R$. officinalis and T. pallidus essential oils (Table 2) shows that seven compounds representing $98.41 \%$ were identified in T. pallidus essential oil, with $O$-cymene $(47.05 \%)$ as the major constituent, in addition to thymol $(15.63 \%)$, $\gamma$-terpinene (15.51\%), linalyl acetate (7.95\%), borneol (6.93\%) and caryophyllene (3.9\%). Thirty three compounds were identified in R. officinalis essential oil, mainly composed by 1,8-cineole (26.07\%), camphor (11.2\%), pinene (8.4\%), $\beta$-pinene (7.27\%) caryophyllene (6.89\%) and borneol (6.62\%).

\subsection{Activity of essential oils against various Gram-negative resistant strains}

The activity of essential oils and standard antibiotics against E. coli, E. aerogenes, $K$. pneumoniae and $P$. aeruginosa is summarised in Table 3. Thymus maroccanus and T. broussonetii had comparative activity against the tested bacteria, with MICs ranging from $0.936 \mathrm{~mL} / \mathrm{L}$ to $0.468 \mathrm{~mL} / \mathrm{L}$ for $\mathrm{AG} 102$ and $\mathrm{EA} 27$ overexpressing the AcrAB pump and from $0.234 \mathrm{~mL} / \mathrm{L}$ to $0.117 \mathrm{~mL} / \mathrm{L}$ for EAEP294 and AG100A, respectively, deleted of AcrAB. The activity of T. pallidus was reduced and the $R$. 
officinalis essential oil demonstrated poor efficacy, with MICs of $3.75 \mathrm{~mL} / \mathrm{L}$ for EAEP294 and AG100A. For strains overexpressing efflux pumps (EA27 and AG102), MICs ranged from $30 \mathrm{~mL} / \mathrm{L}$ to $60 \mathrm{~mL} / \mathrm{L}$. Regarding the $K$. pneumoniae strains, KPBj1E+ and KPBj1Rev presented the same susceptibility to T. maroccanus and $T$. broussonetii; only $T$. pallidus and $R$. officinalis showed a difference between the two strains.

Regarding $P$. aeruginosa, essential oils had the same activity against the two strains (PA01 and PA124). The MIC was $15 \mathrm{~mL} / \mathrm{L}$ for $T$. maroccanus and $\geq 30 \mathrm{~mL} / \mathrm{L}$ for $T$. broussonetii, the highest values obtained for these two essential oils.

In combination with PA $\beta N$ (Table 4), the MIC of EA27 and AG102 that overexpress the AcrAB pump decreased 4-8 times for T. maroccanus, T. broussonetii and $T$. pallidus, whereas for $R$. officinalis the decrease was ca. 32 times. The chemosensitising effect of PA $\beta N$ was less important for EAEP294 and AG100A that are deleted of $\operatorname{acr} A B$, with the reduction corresponding to only two times the MIC for $R$. officinalis and no reduction for the other tested essential oils. The MIC decrease for K. pneumoniae strains was greater (8-16 times), except for KPBj1Rev where it was approximately two times for T. broussonetii and T. pallidus. Interestingly, for the $P$. aeruginosa strains, $\mathrm{PA} \beta \mathrm{N}$ significantly reduced resistance to essential oils in the same way; the MIC dropped from $\mathrm{mL} / \mathrm{L} 15$ to $0.234 \mathrm{~mL} / \mathrm{L}$ and from $\geq 30 \mathrm{~mL} / \mathrm{L}$ to $0.117 \mathrm{~mL} / \mathrm{L}$ for $T$. maroccanus and $T$. broussonetii, respectively. 


\subsection{Activity of essential oils on lipopolysaccharide deep-rough mutants}

In Gram-negative bacteria, LPS constitutes the outer leaflet of the outer membrane and strongly controls the penetration of antibacterial agents [31]. Recently, involvement of intact LPS in resistance to new antibacterial molecules has been described [32]. The activity of essential oils against $S$. Typhimurium strains (Table 5) indicated that SL696 is more resistant to T. maroccanus and T. broussonetii essential oils than SL1069 deleted of a distal part of LPS, which is itself more resistant than SL1102 in which LPS was deleted of a major part. The MICs obtained for $T$. maroccanus and $T$. broussonetii on LPS-truncated mutants are quite similar to those observed with acrAB E. coli mutants (Table 4). Interestingly, in the presence of PA $\beta N$ the MIC for SL696, SL1102 and SL1069 was reduced by 2-, 16- and 32-fold, respectively, for $T$. broussonetii and by 2-, 8- and 16-fold, respectively, for $T$. maroccanus.

3.3. Effect of Thymus maroccanus and Thymus broussonetii oils on chloramphenicol susceptibility of various resistant strains

To evaluate the ability of essential oils to reduce chloramphenicol resistance of different strains, the effect of $T$. maroccanus and $T$. broussonetii was investigated on E. aerogenes (ATCC 13048 and EA27) and E. coli (AG100 and AG102) (Table 6). For E. aerogenes ATCC 13048 used as susceptible strain, T. maroccanus and T. broussonetii decreased the MIC of chloramphenicol from $8 \mathrm{mg} / \mathrm{L}$ to $2 \mathrm{mg} / \mathrm{L}$ and a similar reduction was observed with PA $\beta N$. Regarding the strains that overexpress efflux pumps (EA27 and AG102), the MIC decreased ca. 8-16-fold and 32-fold, respectively, comparable with that obtained with PA $\beta N$. 
For $P$. aeruginosa strains, the two essential oils were used at $7.5 \mathrm{~mL} / \mathrm{L}, 3.75 \mathrm{~mL} / \mathrm{L}$ and $1.87 \mathrm{~mL} / \mathrm{L}$ in combination with chloramphenicol. These concentrations corresponded to $1 / 2,1 / 4,1 / 8$ and $1 / 16$ of the MICs determined for $T$. maroccanus and T. broussonetii, respectively (Table 3). At $7.5 \mathrm{~mL} / \mathrm{L}(\mathrm{MIC} / 2)$ for $T$. maroccanus and at $7.5 \mathrm{~mL} / \mathrm{L}(\mathrm{MIC} / 4)$ and $3.75 \mathrm{~mL} / \mathrm{L}(\mathrm{MIC} / 8)$ for $T$. broussonetii, these essential oils greatly increased the chloramphenicol susceptibility of $P$. aeruginosa strains (Table 7). The MIC reduction was better, or at least similar, to that observed in the presence of PA $\beta N$. It is interesting to note that the decrease of chloramphenicol MIC appears to be dose-dependent for T. maroccanus and T. broussonetii (Table 7).

\section{Discussion}

The intensive and sometimes inappropriate use of antibacterial agents, including antibiotics, disinfectants, etc. leads to the selection of MDR bacterial populations $[2,4]$. To reduce this emergence and the dissemination of MDR bacteria, new molecules are urgently needed [33]. With original chemically synthesised molecules, natural compounds present interesting antibacterial activities. To assess the involvement of efflux and LPS structure in the activity of essential oils of some Moroccan plants and their possible potency to restore antibiotic efficacy through specific interaction with drug efflux pumps, a set of MDR Gram-negative strains and their derivatives (E. coli, E. aerogenes, K. pneumoniae, S. Typhimurium and $P$. aeruginosa) were studied.

First, the direct activity of essential oils on the bacteria was determined. For all tested essential oils, MICs obtained for EA27 and AG102 that overexpress AcrAB 
were greater than the MIC obtained for isogenic strains deleted of this pump (EAEP294 and AG100A) [24-26]. This demonstrates that the active compounds of tested essential oils can be substrates of the efflux pumps involved in the antibiotic resistance of these bacteria (AcrAB-TolC or MexAB-OprM). These results agree with those recently reported regarding some natural compounds [34]. However, no difference was recorded between the susceptibility of the two strains of $K$.

pneumoniae. This suggests that the presence of a basal level of efflux could be sufficient to expel the active components of the oils or, alternatively, the resistancenodulation-cell division (RND) efflux pump (e.g. AcrAB) could not be the main mechanism of resistance involved in these MDR bacteria against such compounds $[27,34]$. In addition, the natural resistance of Gram-negative bacterial strains to essential oils also involves LPS and there was a decreased level of resistance in strains producing truncated LPS molecules.

The results suggest that the truncated LPS increased the bacterial susceptibility to essential oils probably by facilitating diffusion through the outer membrane or, alternatively, the alteration of LPS structure presensitises the envelope to the effects of natural products. The outer membrane is the first barrier impairing the penetration of toxic molecules and the LPS organises an effective protection against external molecules [31,35-37].

In the presence of PA $\beta N$, a well known efflux pump inhibitor $[17,19]$, the antibacterial activity of essential oils increased significantly. This improvement was specifically observed with bacterial strains that overexpress efflux pumps (EA27, EAEP289, AG102 and KPBj1E+). In contrast, no significant change was observed with the 
mutants exhibiting an acrAB deletion in the presence of PA $\beta N$. Regarding Klebsiella strains, the effect induced by $P A \beta N$ on KPBj1Rev is probably due to the presence of basal expression of a PA $\beta \mathrm{N}$-sensitive efflux pump. These data agree with several recent studies that have reported the involvement of efflux pumps in the resistance of Gram-negative bacteria towards many natural products [21,34,37-39]. It is important to note that $R$. officinalis exhibits a high MIC against the various tested Enterobacteriaceae. When PA $\beta N$ was added the susceptibility increased, suggesting that PA $\beta N$-sensitive efflux is a main barrier for this essential oil.

Pseudomonas aeruginosa is an opportunistic pathogen well described for its high level of resistance towards antimicrobial agents [40], mediated by a combination of different mechanisms including reduced membrane permeability and tripartite multidrug efflux systems such as constitutive MexAB-OprM [8,9,41,42]. To determine the role of MexAB-OprM in $P$. aeruginosa sensibility to Moroccan essential oils, PA $\beta N$ was used in combination with essential oils and antibiotics. Results showed that PA $\beta \mathrm{N}$ strongly increased the susceptibility to $T$. maroccanus and $T$. broussonetii for the two strains of $P$. aeruginosa. Interestingly, no difference was observed in the level of MIC reduction with the two strains PA01 and PA124 (overexpressing OprM).

This suggests that active compounds of essential oils can be substrates of efflux pumps existing in the reference strain of $P$. aeruginosa PA01. These efflux pumps are PA $\beta \mathrm{N}$-sensitive and could be different from those involved in the resistance against usual antibiotics. 
Thymus maroccanus and $T$. broussonetii were evaluated for their ability to reduce resistance to chloramphenicol in certain MDR Gram-negative bacteria. The two essential oils significantly increased the susceptibility of efflux pump-overexpressing strains (EA27 and AG102). At concentrations below the MIC, T. maroccanus and T. broussonetii strongly increased the susceptibility of $P$. aeruginosa strains (PA01 and PA124) to chloramphenicol. This result supports the hypothesis that some compounds in the various essential oils are able to block the efflux of usual antibiotics, as previously reported [21]. This active compound can restore susceptibility to chloramphenicol by producing a competition to drug efflux by a mechanism similar to 5'-methoxyhydnocarpin that inhibits efflux of hydrophobic alkaloid berberine in resistant bacteria $[23,43]$. More interestingly, this study demonstrated the ability of low concentrations of $T$. maroccanus and $T$. broussonetii essential oils to restore antibiotic susceptibility in resistant effluxing bacteria.

\section{Acknowledgments}

The authors thank Prof. Ahmad Ouhammou (Université Cadi Ayyad, Marrakech, Morocco) for his generous co-operation to identify plants used in this work. Many thanks go to Prof. Sami Sayadi (Centre de Biotechnologie de Sfax, Tunisia) and Dr Jacques Kaloustian (Université de la Méditerranée, Marseille, France) for help in essential oil analysis by GC/MS as well as Jean-Michel Bolla and Jean-Michel Brunel for fruitful discussions. Special thanks to Mohamed Baz (Université Cadi Ayyad) who gave insightful advice and help.

\section{Funding}


This work was partially supported by the programme Averroes-Erasmus Mundus (to MF) and 'Université de la Méditerranée and Service de Santé des Armées' (Marseille, France).

\section{Competing interests}

None declared.

\section{Ethical approval}

Not required. 


\section{References}

[1] Blot S, Depuydt P, Vandewoude K, De Bacquer D. Measuring the impact of multidrug resistance in nosocomial infection. Curr Opin Infect Dis 2007;20:391-6.

[2] Chopra I, Schofield C, Everett M, O'Neill A, Miller K, Wilcox M, et al. Treatment of health-care-associated infections caused by Gram-negative bacteria: a consensus statement. Lancet Infect Dis 2008;8:133-9.

[3] Bush K, Miller GH. Bacterial enzymatic resistance: $\beta$-lactamases and aminoglycoside-modifying enzymes. Curr Opin Microbiol 1998;1:509-15.

[4] Alekshun MN, Levy SB. Molecular mechanisms of antibacterial multidrug resistance. Cell 2007;128:1037-50.

[5] Tenover FC. Mechanisms of antimicrobial resistance in bacteria. Am J Med 2006;119(6 Suppl 1):S3-10.

[6] Pagès J-M, James CE, Winterhalter M. The porin and the permeating antibiotic: a selective diffusion barrier in Gram-negative bacteria. Nat Rev Microbiol 2008;6:893-903.

[7] Davin-Regli A, Bolla JM, James CE, Lavigne JP, Chevalier J, Garnotel E, et al. Membrane permeability and regulation of drug 'influx and efflux' in enterobacterial pathogens. Curr Drug Targets 2008;9:750-9.

[8] Piddock L. Clinically relevant chromosomally encoded multidrug resistance efflux pumps in bacteria. Clin Microbiol Rev 2006;19:382-402.

[9] Poole K. Efflux-mediated multiresistance in Gram-negative bacteria. Clin Microbiol Infect 2004;10:12-26.

[10] Webber MA, Piddock LJ. The importance of efflux pumps in bacterial antibiotic resistance. J Antimicrob Chemother 2003;51:9-11. 
[11] Li XZ, Nikaido H. Efflux-mediated drug resistance in bacteria: an update. Drugs 2009;69:1555-623.

[12] Van Bambeke F, Balzi E, Tulkens PM. Antibiotic efflux pumps. Biochem Pharmacol 2000;60:457-70.

[13] Pagès J-M, Alibert-Franco S, Mahamoud A, Bolla JM, Davin-Regli A, Chevalier J, et al. Efflux pumps of Gram-negative bacteria, a new target for new molecules. Curr Top Med Chem 2010;8:1848-57.

[14] Chevalier J, Atifi S, Eyraud A, Mahamoud A, Barbe J, Pagès J-M. New pyridoquinoline derivatives as potential inhibitors of the fluoroquinolone efflux pump in resistant Enterobacter aerogenes strains. J Med Chem 2001;44:4023-6.

[15] Guillier M, Gottesman S, Storz G. Modulating the outer membrane with small RNAs. Genes Dev 2006;20:2338-48.

[16] Kristiansen MM, Leandro C, Ordway D, Martins M, Viveiros M, Pacheco T, et al. Thioridazine reduces resistance of methicillin-resistant Staphylococcus aureus by inhibiting a reserpine-sensitive efflux pump. In Vivo 2006;20:361-6.

[17] Lomovskaya O, Bostian KA. Practical applications and feasibility of efflux pump inhibitors in the clinic-a vision for applied use. Biochem Pharmacol 2006;71:910-8.

[18] Malléa M, Chevalier J, Bornet C, Eyraud A, Davin-Regli A, Bollet C, et al. Porin alteration and active efflux: two in vivo drug resistance strategies used by Enterobacter aerogenes. Microbiology 1998;144:3003-9.

[19] Pagès J-M, Amaral L. Mechanisms of drug efflux and strategies to combat them: challenging the efflux pump of Gram-negative bacteria. Biochim Biophys Acta $2009 ; 1794: 826-33$. 
[20] Jodoin J, Demeule M, Beliveau R. Inhibition of the multidrug resistance Pglycoprotein activity by green tea polyphenols. Biochim Biophys Acta 2002;1542:149-59.

[21] Lorenzi V, Muselli A, Bernardini AF, Berti L, Pagès JM, Amaral L, et al. Geraniol restores antibiotic activities against multidrug-resistant isolates from Gram-negative species. Antimicrob Agents Chemother 2009;53:2209-11.

[22] Stavri M, Piddock LJV, Gibbons S. Bacterial efflux pump inhibitors from natural sources. J Antimicrob Chemother 2007;59:1247-60.

[23] Stermitz FR, Lorenz P, Tawara JN, Zenewicz LA, Lewis K. Synergy in a medicinal plant: antimicrobial action of berberine potentiated by $5^{\prime}-$ methoxyhydnocarpin, a multidrug pump inhibitor. Proc Natl Acad Sci U S A 2000;97:1433-7.

[24] Pradel E, Pagès JM. The AcrAB-TolC efflux pump contributes to multidrug resistance in the nosocomial pathogen Enterobacter aerogenes. Antimicrob Agents Chemother 2002;46:2640-3.

[25] Viveiros M, Jesus A, Brito M, Leandro C, Martins M, Ordway D, et al. Inducement and reversal of tetracycline resistance in Escherichia coli K-12 and expression of proton gradient-dependent multidrug efflux pump genes. Antimicrob Agents Chemother 2005;49:3578-82.

[26] Elkins CA, Mullis LB. Substrate competition studies using whole-cell accumulation assays with the major tripartite multidrug efflux pumps of Escherichia coli. Antimicrob Agents Chemother 2007;51:923-9.

[27] Bialek S, Lavigne J-P, Chevalier J, Marcon E, Leflon-Guibout V, Davin A, et al. Membrane efflux and influx modulate both multidrug resistance and virulence 
of Klebsiella pneumoniae in a Caenorhabditis elegans model. Antimicrob Agents Chemother 2010;54:4373-8.

[28] Plésiat P, Nikaido H. Outer membranes of Gram-negative bacteria are permeable to steroid probes. Mol Microbiol 1992;6:1323-33.

[29] Saad A, Fadli M, Bouaziz M, Benharref A, Mezrioui NE, Hassani L. Anticandidal activity of the essential oils of Thymus maroccanus and Thymus broussonetii and their synergism with amphotericin B and fluconazol. Phytomedicine 2010;17:1057-60.

[30] Fadli M, Saad A, Mezrioui N-E, Benharref A, Hassani L. Antibacterial activity of essential oil of three Moroccan thyme species: Thymus maroccanus, Thymus broussonetii, and Thymus pallidus against nosocomial infections-bacteria. In: 1st Euro-Mediterranean Symposium: Plant natural products: from biodiversity to bioindustry; 8-10 December 2009; Cairo, Egypt. Cairo, Egypt: National Research Centre; 2009. p. 93.

[31] Nikaido H. Molecular basis of bacterial outer membrane permeability revisited. Microbiol Mol Biol Rev 2003;67:593-656.

[32] Mamelli L, Petit S, Chevalier J, Giglione C, Lieutaud A, Meinnel T, et al. New antibiotic molecules: bypassing the membrane barrier of Gram negative bacteria increases the activity of peptide deformylase inhibitors. PLoS One 2009;4:e6443.

[33] Jones D. News and analysis: the antibacterial lead discovery challenge. Nature 2010;9:751-2.

[34] Kuete V, Alibert-Franco S, Eyong KO, Ngameni B, Folefoc GN, Nguemeving $\mathrm{JR}$, et al. Antibacterial activity of some natural products against bacteria expressing a multidrug-resistant phenotype. Int J Antimicrob Agents $2011 ; 37: 156-61$. 
[35] Nikaido H. Outer membrane of Salmonella typhimurium: transmembrane diffusion of some hydrophobic substances. Biochim Biophys Acta 1976;433:11832.

[36] Nikaido H. Prevention of drug access to bacterial targets: permeability barriers and active efflux. Science 1994;264:382-8.

[37] Nikaido H. Preventing drug access to targets: cell surface permeability barriers and active efflux in bacteria. Semin Cell Dev Biol 2001;12:215-23.

[38] Papadopoulos CJ, Carson CF, Chang BJ, Riley TV. Role of the MexAB-OprM efflux pump of Pseudomonas aeruginosa in tolerance to tea tree (Melaleuca alternifolia) oil and its monoterpene components terpinen-4-ol, 1,8-cineole, and $\alpha$ terpineol. Appl Environ Microbiol 2008;74:1932-5.

[39] Saleem M, Nazir M, Ali MS, Hussain H, Lee YS, Riaz N, et al. Antimicrobial natural products: an update on future antibiotic drug candidates. Nat Prod Rep 2010:238-54.

[40] Driscoll JA, Brody SL, Kollef MH. The epidemiology, pathogenesis and treatment of Pseudomonas aeruginosa infections. Drugs 2007;67:351-68.

[41] Hancock RE. Resistance mechanisms in Pseudomonas aeruginosa and other nonfermentative Gram-negative bacteria. Clin Infect Dis 1998;27(Suppl 1):S93-9.

[42] Poole K. Multidrug efflux pumps and antimicrobial resistance in Pseudomonas aeruginosa and related organisms. J Mol Microbiol Biotechnol 2001;3:255-64.

[43] Lewis K, Ausubel FM. Prospects for plant-derived antibacterials. Nat Biotechnol 2006;24:1504-7. 


\section{Table 1}

Bacterial strains used in this study

Bacterial Major characteristics
strain

Enterobacter aerogenes

ATCC Reference strain

13048

EA27

MDR clinical isolate; $\mathrm{Kan}^{r} \mathrm{Amp}^{r} \mathrm{Chl}^{r} \mathrm{Nal}^{r} \mathrm{Str}^{r} \mathrm{Tet}^{r}$

EAEP289 Kan ${ }^{\text {s }}$ derivative of EA27

EAEP294 EAEP289 acrA::Kan ${ }^{r}$ (pEP755 integration)

Escherichia coli

AG100 Wild-type E. coli K-12

AG100A AG100 $\triangle a c r A B:: K^{r}{ }^{r}$

AG102 AG100 overproducing AcrAB pump

Klebsiella pneumoniae

$\mathrm{KPBj} 1 \mathrm{E}+\quad$ Clinical isolate resistant to cefoxitin, quinolones and chloramphenicol related to an overexpressed efflux system

KPBj1Rev Spontaneous reverted strain derivative of KPBj1E+, ertapenem sensitive

Salmonella enterica serotype Typhimurium

SL696 Wild-type, metA22, trpB2, strAi20

SL1069 Rc SL696 Rc derivative

SL1102 Re SL696 Re derivative

Pseudomonas aeruginosa

PA01

Reference strain

PA124 Clinical MDR isolate overexpressing OprM

MDR, multidrug-resistant; $\mathrm{Kan}^{r}, \mathrm{Amp}^{r}, \mathrm{Chl}^{r}, \mathrm{Nal}^{r}, \mathrm{Str}^{r}$ and $\mathrm{Tet}^{r}$, resistance to kanamycin, ampicillin, chloramphenicol, nalidixic acid, streptomycin and tetracycline, respectively; Kans, susceptible to kanamycin. 


\section{Table 2}

Chemical composition of Rosmarinus officinalis and Thymus pallidus essential oils

\begin{tabular}{|c|c|c|c|}
\hline $\mathrm{KI}$ & Component & R. officinalis (\%) & T. pallidus (\%) \\
\hline 929 & Tricyclene & 0.20 & $\mathrm{~N} / \mathrm{D}$ \\
\hline 937 & $\alpha$-Thujene & 0.32 & $\mathrm{~N} / \mathrm{D}$ \\
\hline 947 & Pinene & 8.40 & N/D \\
\hline 963 & Camphene & 5.14 & $\mathrm{~N} / \mathrm{D}$ \\
\hline 999 & $\beta$-Pinene & 7.27 & $\mathrm{~N} / \mathrm{D}$ \\
\hline 1009 & Myrcene & 2.17 & N/D \\
\hline 1019 & 1-Phellandrene & 0.41 & N/D \\
\hline 1028 & $\alpha$-Terpinene & 1.32 & $\mathrm{~N} / \mathrm{D}$ \\
\hline 1041 & 1,8-Cineole & 26.07 & $\mathrm{~N} / \mathrm{D}$ \\
\hline 1050 & O-cymene & 0.17 & 47.05 \\
\hline 1057 & $\gamma$-Terpinene & 2.20 & 15.51 \\
\hline- & Linalyl acetate & $\mathrm{N} / \mathrm{D}$ & 7.95 \\
\hline 1076 & Terpinolene & 0.96 & N/D \\
\hline 1105 & Fenchol & 0.07 & N/D \\
\hline 1151 & Camphor & 11.20 & N/D \\
\hline 1198 & Borneol & 6.62 & 6.93 \\
\hline 1227 & $\alpha$-Terpineol & 4.76 & $\mathrm{~N} / \mathrm{D}$ \\
\hline 1238 & Verbenone & 0.42 & N/D \\
\hline 1313 & L-Bornyl acetate & 2.64 & N/D \\
\hline 1347 & Thymol & 0.31 & 15.63 \\
\hline 1358 & Carvacrol & 1.04 & 1.45 \\
\hline 1378 & $\alpha$-Cubebene & 0.15 & $\mathrm{~N} / \mathrm{D}$ \\
\hline 1402 & Ylangene & 0.35 & $N / D$ \\
\hline 1408 & Copaene & 0.95 & N/D \\
\hline 1441 & Methyl eugenol & 0.18 & $\mathrm{~N} / \mathrm{D}$ \\
\hline 1456 & Caryophyllene & 6.89 & 3.9 \\
\hline 1488 & Humulene & 1.31 & N/D \\
\hline 1510 & $\alpha$-Amorphene & 0.89 & $N / D$ \\
\hline 1524 & Aromadendrene & 0.07 & $\mathrm{~N} / \mathrm{D}$ \\
\hline
\end{tabular}




\begin{tabular}{llll}
\hline 1535 & $\alpha$-Muurolene & 0.89 & $\mathrm{~N} / \mathrm{D}$ \\
1542 & $\Delta$-Cadinene & 0.23 & $\mathrm{~N} / \mathrm{D}$ \\
1553 & $\gamma$-Cadinene & 0.35 & $\mathrm{~N} / \mathrm{D}$ \\
1627 & Oxide de caryophyllene & 0.25 & $\mathrm{~N} / \mathrm{D}$ \\
- & Linoleic acid & 0.15 & $\mathrm{~N} / \mathrm{D}$ \\
Total & & $94.35 \%$ & 98.41 \\
\hline
\end{tabular}

$\mathrm{KI}$, Kovats index; N/D, not detected. 


\section{Table 3}

Minimum inhibitory concentrations (MICs) of essential oils and antibiotics against tested Gram-negative bacteria

\begin{tabular}{|c|c|c|c|c|c|c|c|}
\hline \multirow[t]{2}{*}{ Strain } & \multicolumn{4}{|c|}{ MIC of essential oils (mL/L) } & \multicolumn{3}{|c|}{ MIC of antibiotics $(\mathrm{mg} / \mathrm{L})$} \\
\hline & TM & TB & TP & RO & NOR & CLX & $\mathrm{CHL}$ \\
\hline \multicolumn{8}{|c|}{ Enterobacter aerogenes } \\
\hline ATCC 13048 & 0.468 & 0.936 & 1.875 & 30 & 0.06 & 512 & 8 \\
\hline EA27 & 0.468 & 0.468 & 1.875 & 30 & 64 & 2048 & 1024 \\
\hline EAEP289 & 0.936 & 1.875 & 7.5 & 60 & 64 & 2048 & 1024 \\
\hline EAEP294 & 0.234 & 0.234 & 0.468 & 3.75 & 8 & 1024 & 64 \\
\hline
\end{tabular}

Escherichia coli

$\begin{array}{llllllll}\text { AG100 } & 0.936 & 0.936 & 3.75 & 15 & 0.06 & 512 & 8 \\ \text { AG102 } & 0.468 & 0.936 & 7.5 & 30 / 60^{\mathrm{a}} & 0.125 & 512 & 32 \\ \text { AG100A } & 0.117 & 0.117 & 0.234 & 3.75 & 0.015 & 2 & 0.5\end{array}$

Klebsiella pneumoniae

$\begin{array}{llllllll}\text { KPBj1E+ } & 1.875 & 1.875 & 3.75 & >15 & 4 & 1024 & 128 \\ \text { KPBj1Rev } & 1.875 & 1.875 & 1.875 & 15 & 0.25 & 512 & 4\end{array}$

Pseudomonas aeruginosa

$\begin{array}{llllllll}\text { PA01 } & 15 & 30 & \mathrm{~N} / \mathrm{D} & >30 & 0.5 & 4096 & 32\end{array}$

$\begin{array}{llllllll}\text { PA124 } & 15 & >30 & \text { N/D } & >30 & 64 & >4096 & 256\end{array}$

TM, Thymus maroccanus; TB, Thymus broussonetii; TP, Thymus pallidus; RO,

Rosmarinus officinalis; NOR, norfloxacin; CLX, cloxacillin; CHL, chloramphenicol;

$\mathrm{N} / \mathrm{D}$, not determined.

${ }^{a}$ Variation of one dilution when MICs determined separately in different experiments. 


\section{Table 4}

Minimum inhibitory concentrations (MICs) of essential oils and antibiotics in combination with phenylalanine arginyl $\beta$ naphthylamide $(\mathrm{PA} \beta \mathrm{N})(20 \mathrm{mg} / \mathrm{L})$ against tested Gram-negative bacteria

\begin{tabular}{|c|c|c|c|c|c|c|c|c|c|c|c|c|c|c|}
\hline \multirow[t]{4}{*}{ Strain } & \multicolumn{8}{|c|}{ MIC of essential oils (mL/L) } & \multicolumn{6}{|c|}{ MIC of antibiotics (mg/L) } \\
\hline & \multicolumn{2}{|l|}{ TM } & \multicolumn{2}{|l|}{ TB } & \multicolumn{2}{|l|}{ TP } & \multicolumn{2}{|l|}{$\mathrm{RO}$} & \multicolumn{2}{|l|}{ NOR } & \multicolumn{2}{|l|}{ CLX } & \multicolumn{2}{|l|}{$\mathrm{CHL}$} \\
\hline & - & $+\mathrm{PA} \beta \mathrm{N}$ & - & $+\mathrm{PA} \beta \mathrm{N}$ & - & $+\mathrm{PA} \beta \mathrm{N}$ & - & $+\mathrm{PA} \beta \mathrm{N}$ & - & $+\mathrm{PA} \beta \mathrm{N}$ & - & $+\mathrm{PA} \beta \mathrm{N}$ & - & $+\mathrm{PA} \beta \mathrm{N}$ \\
\hline & \multicolumn{2}{|l|}{$P A \beta N$} & \multicolumn{2}{|l|}{$P A \beta N$} & \multicolumn{2}{|l|}{$P A \beta N$} & \multicolumn{2}{|l|}{$\mathrm{PA} \beta \mathrm{N}$} & \multicolumn{2}{|l|}{$\mathrm{PA} \beta \mathrm{N}$} & \multicolumn{2}{|l|}{$\mathrm{PA} \beta \mathrm{N}$} & \multicolumn{2}{|l|}{$\mathrm{PA} \beta \mathrm{N}$} \\
\hline \multicolumn{15}{|c|}{ Enterobacter aerogenes } \\
\hline \multicolumn{15}{|l|}{13048} \\
\hline EA27 & 0.468 & 0.117 & 0.468 & 0.117 & 1.875 & 0.468 & 30 & 0.936 & 64 & 64 & 2048 & 1024 & 1024 & 64 \\
\hline EAEP289 & 0.936 & 0.234 & 1.875 & 0.234 & 7.5 & 0.936 & 60 & 1.875 & 64 & 64 & 2048 & 1024 & 1024 & 256 \\
\hline EAEP294 & 0.234 & 0.234 & 0.234 & 0.234 & 0.468 & 0.468 & 3.75 & 1.875 & 8 & 8 & 1024 & 256 & 64 & 32 \\
\hline \multicolumn{15}{|c|}{ Escherichia coli } \\
\hline AG100A & 0.117 & 0.117 & 0.117 & 0.117 & 0.234 & 0.234 & 3.75 & 1.875 & 0.015 & 0.002 & 2 & $<0.06$ & 0.5 & 0.25 \\
\hline \multicolumn{15}{|c|}{ Klebsiella pneumoniae } \\
\hline KPBj1E+ & 1.875 & 0.117 & 1.875 & 0.234 & 3.75 & 0.468 & $>15$ & 1.875 & 4 & 0.5 & 1024 & 64 & 128 & 1 \\
\hline
\end{tabular}




\begin{tabular}{lccccccccccccccc}
\hline KPBj1Rev & 1.875 & 0.234 & 1.875 & 0.936 & 1.875 & 0.936 & 15 & 1.875 & 0.25 & 0.125 & 512 & 256 & 4 & 0.5 & \\
$\begin{array}{l}\text { Pseudomonas aeruginosa } \\
\text { PA01 }\end{array}$ & 15 & 0.234 & 30 & 0.117 & N/D & N/D & $>30$ & 7.5 & 0.5 & 0.125 & 4096 & 512 & 32 & 1 \\
PA124 & 15 & 0.234 & $>30$ & 0.117 & N/D & N/D & $>30$ & 7.5 & 64 & 32 & $>4096$ & 2048 & 256 & 4 &
\end{tabular}

TM, Thymus maroccanus; TB, Thymus broussonetii; TP, Thymus pallidus; RO, Rosmarinus officinalis; NOR, norfloxacin; CLX, cloxacillin; CHL, chloramphenicol; N/D, not determined.

${ }^{\text {a }}$ Variation of one dilution when MICs determined separately in different experiments. 


\section{Table 5}

Minimum inhibitory concentrations (MICs) of essential oils and antibiotics in combination with phenylalanine arginyl $\beta$ naphthylamide $(\mathrm{PA} \beta \mathrm{N})(20 \mathrm{mg} / \mathrm{L})$ against Salmonella enterica serotype Typhimurium strains

\begin{tabular}{|c|c|c|c|c|c|c|c|c|c|c|}
\hline \multirow[t]{3}{*}{ Strain } & \multicolumn{4}{|c|}{ MIC of essential oils (mL/L) } & \multicolumn{6}{|c|}{ MIC of antibiotics (mg/L) } \\
\hline & \multicolumn{2}{|l|}{ TM } & \multicolumn{2}{|l|}{ TB } & \multicolumn{2}{|l|}{ NOR } & \multicolumn{2}{|l|}{ CLX } & \multicolumn{2}{|l|}{$\mathrm{CHL}$} \\
\hline & $-\mathrm{PA} \beta \mathrm{N}$ & $+\mathrm{PA} \beta \mathrm{N}$ & $-\mathrm{PA} \beta \mathrm{N}$ & $+\mathrm{PA} \beta \mathrm{N}$ & $-\mathrm{PA} \beta \mathrm{N}$ & $+\mathrm{PA} \beta \mathrm{N}$ & $-P A \beta N$ & $+\mathrm{PA} \beta \mathrm{N}$ & $-\mathrm{PA} \beta \mathrm{N}$ & $+\mathrm{PA} \beta \mathrm{N}$ \\
\hline SL696 & 0.468 & 0.234 & 1.875 & 0.93 & 0.25 & 0.015 & $>2048$ & 1024 & 4 & 0.5 \\
\hline SL1069 Rc & 0.234 & $<0.015$ & 0.468 & $<0.015$ & 0.06 & $<0.015$ & 2048 & $<0.5$ & $1 / 0.5^{a}$ & $<0.015$ \\
\hline SL1102 Re & 0.117 & $<0.015$ & 0.234 & $<0.015$ & 0.06 & $<0.015$ & 32 & $<0.5$ & $1 / 0.5^{a}$ & $<0.015$ \\
\hline
\end{tabular}

TM, Thymus maroccanus; TB, Thymus broussonetii; NOR, norfloxacin; CLX, cloxacillin; CHL, chloramphenicol.

a Variation of one dilution when MICs determined separately in different experiments. 


\section{Table 6}

Minimum inhibitory concentrations (MICs) of chloramphenicol in combination with

Thymus maroccanus and Thymus broussonetii against Enterobacter aerogenes and Escherichia coli strains

\begin{tabular}{lllll}
\hline Combination & \multicolumn{4}{l}{ MIC of chloramphenicol (mg/L) } \\
\cline { 2 - 5 } & E. aerogenes & E. aerogenes & E. coli & E. coli \\
& ATCC 13048 & EA27 & AG100 & AG102 \\
\hline Chloramphenicol & 8 & 1024 & 8 & 32 \\
Chloramphenicol + PA $\beta \mathrm{N}$ & 2 & 64 & 2 & 1 \\
Gain & 4 & 16 & 4 & 32 \\
Chloramphenicol + T. & 2 & $128 / 64$ & $2 / 1$ & 1 \\
maroccanus $0.31 \mathrm{~mL} / \mathrm{L}$ & & & & \\
Gain & 4 & $8 / 16$ & $4 / 8$ & 32 \\
Chloramphenicol $+\mathrm{T}$. & 2 & $128 / 64$ & 2 & 1 \\
$\quad$ broussonetii $0.31 \mathrm{~mL} / \mathrm{L}$ & & & & 32 \\
Gain & 4 & $8 / 16$ & 4 & 32 \\
\hline
\end{tabular}

PA $\beta N$, phenylalanine arginyl $\beta$-naphthylamide. 


\section{Table 7}

Minimum inhibitory concentrations (MICs) of chloramphenicol (CHL) in combination with Thymus maroccanus and Thymus broussonetii against Pseudomonas aeruginosa strains

\begin{tabular}{|c|c|c|c|c|c|c|c|c|c|c|c|c|c|c|c|}
\hline \multirow[t]{2}{*}{ Strain } & \multirow{2}{*}{$\begin{array}{l}\text { MIC } \\
\text { (mg/L) of } \\
\mathrm{CHL}\end{array}$} & \multicolumn{2}{|c|}{$\begin{array}{l}\mathrm{MIC}(\mathrm{mg} / \mathrm{L}) \text { of } \\
\mathrm{CHL}+\mathrm{PA} \beta \mathrm{N}\end{array}$} & \multicolumn{5}{|c|}{$\mathrm{MIC}(\mathrm{mg} / \mathrm{L})$ of $\mathrm{CHL}+T$. maroccanus } & \multicolumn{7}{|c|}{$\mathrm{MIC}(\mathrm{mg} / \mathrm{L})$ of $\mathrm{CHL}+T$. broussonetii } \\
\hline & & $20 \mathrm{mg} / \mathrm{L}$ & Gain & $\begin{array}{l}7.5 \\
\mathrm{~mL} / \mathrm{L}\end{array}$ & Gain & $\begin{array}{l}3.75 \\
\mathrm{~mL} / \mathrm{L}\end{array}$ & Gain & $\begin{array}{l}1.87 \\
\mathrm{~mL} / \mathrm{L}\end{array}$ & Gain & $\begin{array}{l}7.5 \\
\mathrm{~mL} / \mathrm{L}\end{array}$ & Gain & $\begin{array}{l}3.75 \\
\mathrm{~mL} / \mathrm{L}\end{array}$ & Gain & $\begin{array}{l}1.87 \\
\mathrm{~mL} / \mathrm{L}\end{array}$ & Gain \\
\hline PA01 & 32 & 1 & 32 & $<0.5$ & $>64$ & 4 & 8 & 8 & 4 & $<0.5$ & $>64$ & 4 & 8 & 16 & 2 \\
\hline PA124 & 256 & 32 & 8 & 32 & 8 & 32 & 8 & 64 & 4 & 32 & 8 & 32 & 8 & 64 & 4 \\
\hline
\end{tabular}

PA $\beta N$, phenylalanine arginyl $\beta$-naphthylamide. 